\title{
Nutrient Dynamics in Blackgram (Vigna mungo) Grown Vertisols as Influenced by Co-inoculation of Different Bacterial Cultures with Rhizobium phaseoli
}

\author{
K. M. Nelwade*, Syed Ismail and R. A. Jadhav \\ Department of Soil Science and Agricultural Chemistry, \\ Vasantrao Naik Marathwada Krishi Vidyapeeth, Parbhani, Maharashtra 431402, India \\ *Corresponding author
}

\section{A B S T R A C T}

\section{Keywords}

Nutrient dynamics,

Co-inoculation,

Black gram

Article Info

Accepted:

07 September 2019

Available Online:

10 October 2019
A field experiment was conducted during kharif season of 2018 at Research Farm, Department of Soil Science and Agricultural Chemistry, Vasantrao Naik Marathwada Krishi Vidyapeeth, Parbhani to assess the co-inoculation effect of different bacterial cultures with Rhizobium phaseoli on nutrient dynamics. Experiment consist of ten treatments in which eight pre-evaluated bacterial cultures in laboratory (Rhizobium phaseoli, Bacillus megaterium, Bacillus subtilis, Bacillus polymyxa, Pseudomonas striata, Pseudomonas flurescens, Azotobacter chroococcum and Azospirilllum lipoferum) and were used with recommended dose of fertilizer (RDF) in randomized block design. Seed treatment of black gram was done with bacterial cultures along with application RDF at the time of sowing. Results emerged out indicated that the both macronutrient and micronutrient mobilization were significantly improved by co-inoculation over non-inoculation and single inoculation of Rhizobium phaseoli. The co-inoculation of Rhizobium phaseoli + Bacillus megaterium, Rhizobium phaseoli + Pseudomonas striata and Rhizobium phaseoli + Pseudomonas flurescense were found to be at par with each other and having more potential than the other combinations in influencing soil nutrient availability.

\section{Introduction}

Bio-fertilizers play a crucial role in soil health and plant growth as it has efficient strains of nitrogen fixing, phosphate solubilising, potash and micronutrient mobilizers (Verma et al., 2010). In the rhizosphere the synergism between various bacterial genera such as
Bacillus, Pseudomonas and Rhizobium has been demonstrated to promote plant growth and development. Compared to single inoculation, co-inoculation has improved the absorption of nitrogen, phosphorus and mineral nutrients by plants (Dashadi et al., 2011). Microbial consortia behave synergistically by considerably increasing the 
amount of solubilized nutrients, growth hormone production, and ultimately promote plant growth (Mishra et al., 2011). Taking these facts under consideration, it was hypothesized that co-inoculation or composite inoculum of rhizobia and endophytic bacteria has greater potential for plant growth improvement compared to the single strain inoculation.

Blackgram (Urad) is annual pulse crop and native to Central Asia. At national level it is the 3rd important crop, was cultivated over an area of 5.44 Mha (kharif + rabi) and recorded a production of $3.56 \mathrm{Mt}$ at a productivity level of $655 \mathrm{~kg} \mathrm{ha}^{-1}$. Major contributing states have been Madhya Pradesh, Rajasthan, Andhra Pradesh, Uttar Pradesh, Tamil Nadu, Maharashtra, Jharkhand and Gujarat. Maharashtra contribute 9.62 per cent (4.84 lakh ha) to the total area under blackgram and 5.39 per cent (1.77 lakh tones) to the total production (Anonymous 2018). This crop is endowed with many desirable characters like, short in duration, restorative (soil fertility building crops), low water requiring and highly suitable to be grown in mixed or intercropping systems and also as a catch crop to scavenge the residual soil moisture and fertility. It is rich source of deity protein (24\%), carbohydrate (67\%), Fibre $(3.5 \%)$, fat $(1.74 \%)$ and major portion of lysine in a vegetarian diet (Elangaimannan et al., 2008). Black gram is rich in potassium, phosphorous, calcium, sodium and vitamins (retinoic acid, thiamine, riboflavin). It has several therapeutic properties like curing diabetes, sexual dysfunction, and nervous hair and digestive system disorders.

\section{Materials and Methods}

A field experiment was conducted during kharif season of 2018 at Research farm, Department of Soil Science and Agricultural Chemistry, Vasantrao Naik Marathwada
Krishi Vidyapeeth, Parbhani to assess the coinoculation effect of different bacterial cultures with Rhizobium phaseoli on nutrient dynamics. Experiment consist of ten treatments in which eight pre-evaluated bacterial cultures in laboratory (Rhizobium phaseoli, Bacillus megaterium, Bacillus subtilis, Bacillus polymyxa, Pseudomonas striata, Pseudomonas flurescens, Azotobacter chroococcum and Azospirillum lipoferum) and were used with recommended dose of fertilizer (25:50:00:10 N,P,K and $\mathrm{S} \mathrm{kg} \mathrm{ha}{ }^{-1}$ respectively) in randomized block design. Seed treatment of black gram was done with bacterial cultures along with application RDF at the time of sowing. The initial soil $\mathrm{pH}$ was 7.89, EC $0.27 \mathrm{dSm}^{-1}$, organic carbon $3.68 \mathrm{~g}$ $\mathrm{kg}^{-1}$, calcium carbonate $21.6 \mathrm{~g} \mathrm{~kg}^{-1}$, available $\mathrm{N} 164.68 \mathrm{~kg} \mathrm{ha}^{-1}$, available $\mathrm{P}_{2} \mathrm{O}_{5} 13.89 \mathrm{~kg} \mathrm{ha}^{-1}$, available $\mathrm{K}_{2} \mathrm{O} 544.56 \mathrm{~kg} \mathrm{ha}^{-1}$, available zinc $0.40 \mathrm{mg} \mathrm{kg}^{-1}$, available iron $4.39 \mathrm{mg} \mathrm{kg}^{-1}$, available manganese $5.69 \mathrm{mg} \mathrm{kg} \mathrm{kg}^{-1}$ and available copper was $3.20 \mathrm{mg} \mathrm{kg}^{-1}$. The soil was clayey in texture, moderately alkaline in reaction, medium in available nitrogen, phosphorus and sufficient in available potassium and low in iron and zinc. The soil samples we also analysed after harvest of crop and analysed for various soil properties using standard procedures. The results obtained were statistically analyzed and appropriately interpreted as per the methods described by Panse and Sukhatme (1985). Appropriate standard error (S.E.) and critical differences (C.D.) at 5 per cent levels were worked out for interpretation of result.

\section{Results and Discussion}

\section{Effect on physico-chemical properties}

\section{pH, EC and $\mathrm{CaCO}_{3}$}

The result presented in Table 1 regarding changes in soil $\mathrm{pH}, \mathrm{EC}$ and $\mathrm{CaCO}_{3}$ after harvest of black gram indicates non- 
significant impact. In the study, treatments receiving dual inoculation of bacterial cultures with Rhizobium phaseoli showed the physicochemical properties i.e. $\mathrm{pH}, \mathrm{EC}$ and $\mathrm{CaCO}_{3}$ of soil decreased positively. The $\mathrm{pH}$ is an intrinsic property of soil which usually does not change easily. Qureshi et al., (2011) supported our result that lowered the soil $\mathrm{pH}$ due to the production of organic acids. Similarly, Maseko and Dakora (2013) noted that the rhizosphere $\mathrm{pH}$ of different bacterial species was generally lower than that of the corresponding bulk soil, although these were statistically non-significant. Similarly, Kranthikumar et al., (2017a) revealed nonsignificant positive effect in case of $\mathrm{pH}, \mathrm{EC}$ and $\mathrm{CaCO}_{3}$ due to application of bio-fertilizers with Rhizobium.

\section{Organic carbon}

The organic carbon (O.C) content of soil after harvest of black gram ranged between 3.62 to $5.10 \mathrm{~g} \mathrm{~kg}^{-1}$ (Table 1). Soil organic carbon content increased significantly and attained a maximum value of $5.10 \mathrm{~g} \mathrm{~kg}^{-1}$ in the treatment $\mathrm{T}_{7}$ that received co-inoculation of Pseudomonas striata and Rhizobium phaseoli along with $100 \%$ RDF over other treatments and found at par with treatments $\mathrm{T}_{4}\left(4.83 \mathrm{~g} \mathrm{~kg}^{-}\right.$ $\left.{ }^{1}\right)$ having co-inoculation of Bacillus megaterium with Rhizobium phaseoli and $\mathrm{T}_{8}$ (5.05 $\mathrm{g} \mathrm{ha}^{-1}$ ) receiving co-inoculation of Pseudomons flurescens with Rhizobium phaseoli. This could be ascribed to the dual inoculation of bacterial cultures in combination with fertilizers that increased residual biomass through root, leaves, stubles and rhizodeposition which helped in increasing organic matter and alternately soil organic carbon content (Singh et al., 2016). This finding was supported by Goutami et al., (2015) that organic carbon positively increased with level of nitrogen and application of biofertilizers. Furthermore, Qureshi et al., (2011) found that due to co- inoculation of microbial cultures the rate of degradation of soil organic matter increased which ultimately helps in increasing the soil organic carbon.

\section{Effect on macronutrient availability}

The data presented in Table 2 showed that significant increase in nutrient availability in soil after harvest of black gram crop under the influence of co-inoculation of different bacterial cultures with Rhizobium phaseoli.

\section{Available Nitrogen}

Distinct differences in available $\mathrm{N}$ with values lying between 164.53 to $197.29 \mathrm{~kg} \mathrm{ha}^{-1}$ were observed among the treatments. The available $\mathrm{N}$ was the highest in treatment $\mathrm{T}_{7}(197.29 \mathrm{~kg}$ $\mathrm{ha}^{-1}$ ) received co-inoculation of Pseudomonas striata with Rhizobium phaseoli which found significantly superior over rest of treatments at 5 per cent significance level and treatment $\mathrm{T}_{4}$ (192.34 $\mathrm{kg} \mathrm{ha}^{-1}$ ) received co-inoculation of Bacillus megaterium with Rhizobium phaseoli found at par with treatment $T_{7}$. The increase in available $\mathrm{N}$ may be due to dual inoculation of bacterial cultures helping in multiplication of soil microbes and ultimately enhancing the conversion of organically bound $\mathrm{N}$ to mineral form (Singh et al., 2016).

\section{Available phosphorous}

In case of available phosphorous the values were varied from 13.96 to $16.87 \mathrm{~kg} \mathrm{ha}^{-1}$ under the influence of joint effect of Rhizobium phaseoli and bacterial cultures. The maximum $\mathrm{P}$ availability was found in treatment $\mathrm{T}_{8}(16.87$ $\mathrm{kg} \mathrm{ha}{ }^{-1}$ receiving co-inoculation of Pseudomonas flurescens with Rhizobium phaseoli which significantly superior over rest of treatments and found closely at par with $\mathrm{T}_{7}$ $\left(15.68 \mathrm{~kg} \mathrm{ha}^{-1}\right)$ received co-inoculation of Pseudomonas striata with Rhizobium phaseoli. This build up $\mathrm{P}$ in soil is attributed to 
solubilization of native $\mathrm{P}$ through greater release of organic acids under co-inoculation of different bacterial cultures with Rhizobium sp. (Shashidhar et al., 2009).

Qureshi et al., (2011) also noted the highest available $\mathrm{P}$ with Bacillus sp. was observed after 30, 60 and 90 days of sowing at highest $P$ fertilizer level i.e. $90 \mathrm{~kg} \mathrm{P} \mathrm{ha}^{-1}$.

\section{Available potassium}

Regarding to available $\mathrm{K}$, all co-inoculated treatments shows superior values over monoinoculation and un-inoculated control.

The highest available $\mathrm{K}$ was found under the influence of co-inoculation of Pseudomonas striata with Rhizobium phaseoli $\left(\mathrm{T}_{7}-622.71\right.$ $\mathrm{kg} \mathrm{ha}{ }^{-1}$ ) which found significantly superior over other treatments and found at par with treatment $\mathrm{T}_{4}\left(602.13 \mathrm{~kg} \mathrm{ha}^{-1}\right)$ receiving coinoculation of Bacillus megaterium with Rhizobium phaseoli and $\mathrm{T}_{8}\left(612.58 \mathrm{~kg} \mathrm{ha}^{-1}\right)$ receiving co-inoculation of Pseudomonas flurescens with Rhizobium phaseoli.

Earlier, Nirmal et al., (2006) noted that the dual inoculation of Rhizobium and PSB resulted into more availability of nitrogen and phosphorous because of their associative effect of solubilization from non-exchangeable to liable form, which leads to significant increase in growth and yield attributes as compared to single or un-inoculated plot.

Similarly, Kumar et al., (2004) proved to have a favourable effect on the availability of $\mathrm{N}, \mathrm{P}$ and $\mathrm{K}$, thereby indicating the vital role of these organisms in the transformation reaction of these three nutrients in the soil.

Moreover, Dhage et al., (2008) noted that availability of $\mathrm{N}, \mathrm{P}$ and $\mathrm{K}$ recorded in a treatment with $100 \%$ RDF + Rhizobium + PSB over control in soybean. Further, Amule et al., (2013) reported that available N, P and K reflected $2 \%$ increase due to co-inoculation over mono-inoculation. Similarly, Goutami et al., (2015) found that there was significant increase in available $\mathrm{N}, \mathrm{P}$ and $\mathrm{K}$ was observed in the presence of bio-fertilizer consortium and /or FYM over control. Singh et al., (2016) also noted that maximum available nitrogen, phosphorous and potassium was observed in Rhizobium + PSB.

Similarly, Vidhyashree et al., (2017) reported that PSB + Aspergillus awamori inoculation increase availability $\mathrm{N}, \mathrm{P}$ and $\mathrm{K}$ in soil.

\section{Effect on DTPA extractable micronutrients}

The scrutiny of result presented in Table 3 reveals that the available micronutrients (DTPA extractable) in soil after harvest of black gram crop were influenced significantly by co-inoculation of different bacterial cultures with Rhizobium phaseoli.

\section{DTPA extractable zinc}

The availability of $\mathrm{Zn}$ significantly influenced by treatment $\mathrm{T}_{7}\left(0.59 \mathrm{mg} \mathrm{kg}^{-1}\right)$ receiving coinoculation of Pseudomonas striata with Rhizobium phaseoli and found at par with treatment $\mathrm{T}_{8}\left(0.57 \mathrm{mg} \mathrm{kg}^{-1}\right)$ receiving coinoculation of Pseudomonas flurescens with Rhizobium phaseoli and $\mathrm{T}_{4}\left(0.58 \mathrm{mg} \mathrm{kg}^{-1}\right)$ receiving co-inoculation of Bacillus megaterium with Rhizobium phaseoli.

\section{DTPA extractable iron}

In case of $\mathrm{Fe}$ availability the values varied from 4.41 to $5.12 \mathrm{mg} \mathrm{kg}^{-1}$ due to influence of co-inoculation of bacterial cultures with Rhizobium phaseoli. 
Table.1 Effect of co-inoculation of different bacterial cultures with Rhizobium phaseoli on physico-chemical properties of soil after harvest of black gram

\begin{tabular}{|c|c|c|c|c|c|}
\hline $\begin{array}{l}\text { Sr. } \\
\text { No. }\end{array}$ & Treatments & $\underset{(1: 2.5)}{\text { pH }}$ & $\begin{array}{c}\mathrm{EC} \\
\left(\mathrm{dSm}^{-1}\right)\end{array}$ & $\begin{array}{l}\mathrm{CaCO}_{3} \\
\left(\mathrm{~g} \mathrm{~kg}^{-1}\right)\end{array}$ & $\begin{array}{c}\text { Organic } \\
\text { carbon } \\
\left(\mathrm{g} \mathrm{kg}^{-1}\right)\end{array}$ \\
\hline $\mathbf{T}_{1}$ & Absolute control & 7.89 & 0.27 & 21.43 & 3.73 \\
\hline $\mathbf{T}_{2}$ & Only RDF & 7.90 & 0.27 & 20.97 & 3.90 \\
\hline $\mathbf{T}_{\mathbf{3}}$ & RDF + Rhizobium phaseoli & 7.88 & 0.25 & 20.50 & 4.00 \\
\hline $\mathbf{T}_{4}$ & $\mathrm{~T}_{3}+$ Bacillus megaterium & 7.86 & 0.25 & 20.87 & 4.83 \\
\hline $\mathbf{T}_{5}$ & $\mathrm{~T}_{3}+$ Bacillus subtilis & 7.86 & 0.26 & 21.03 & 4.60 \\
\hline $\mathbf{T}_{6}$ & $\mathrm{~T}_{3}+$ Bacillus polymyxa & 7.88 & 0.26 & 21.53 & 4.07 \\
\hline $\mathbf{T}_{7}$ & $\mathrm{~T}_{3}+$ Pseudomonas striata & 7.87 & 0.25 & 21.43 & 5.10 \\
\hline $\mathbf{T}_{8}$ & $\mathrm{~T}_{3}+$ Pseudomonas flurescens & 7.87 & 0.25 & 21.53 & 5.05 \\
\hline $\mathbf{T}_{9}$ & $\mathrm{~T}_{3}+$ Azotobacter chroococcum & 7.88 & 0.27 & 21.37 & 4.47 \\
\hline \multirow[t]{3}{*}{$\mathbf{T}_{10}$} & $\mathrm{~T}_{3}+$ Azospirillum lipoferum & 7.89 & 0.27 & 21.57 & 4.27 \\
\hline & S.E. \pm & 0.013 & 0.006 & 0.32 & 0.15 \\
\hline & C.D. at $5 \%$ & NS & NS & NS & 0.45 \\
\hline
\end{tabular}

Table.2 Effect of co-inoculation of different bacterial cultures with Rhizobium phaseoli on macronutrient availability in soil after harvest of black gram

\begin{tabular}{|c|c|c|c|c|}
\hline $\begin{array}{l}\text { Sr. } \\
\text { No. }\end{array}$ & Treatments & $\begin{array}{c}\text { Available } \\
\mathrm{N} \\
\left(\mathrm{kg} \mathrm{ha}^{-1}\right)\end{array}$ & $\begin{array}{l}\text { Available } \mathrm{P}_{2} \mathrm{O}_{5} \\
\quad\left(\mathrm{~kg} \mathrm{ha}^{-1}\right)\end{array}$ & $\begin{array}{c}\text { Available } \\
\mathrm{K}_{2} \mathrm{O} \\
\left(\mathrm{kg} \mathrm{ha}^{-1}\right)\end{array}$ \\
\hline $\mathbf{T}_{1}$ & Absolute control & 164.53 & 13.96 & 545.57 \\
\hline $\mathbf{T}_{2}$ & Only RDF & 165.17 & 13.98 & 549.33 \\
\hline $\mathbf{T}_{\mathbf{3}}$ & RDF + Rhizobium phaseoli & 180.84 & 14.12 & 563.65 \\
\hline $\mathbf{T}_{4}$ & $\mathrm{~T}_{3}+$ Bacillus megaterium & 192.34 & 15.08 & 602.13 \\
\hline $\mathbf{T}_{5}$ & $\mathrm{~T}_{3}+$ Bacillus subtilis & 179.80 & 15.23 & 594.52 \\
\hline $\mathbf{T}_{6}$ & $\mathrm{~T}_{3}+$ Bacillus polymyxa & 165.16 & 14.08 & 570.58 \\
\hline $\mathbf{T}_{7}$ & $\mathrm{~T}_{3}+$ Pseudomonas striata & 197.29 & 15.68 & 622.71 \\
\hline $\mathbf{T}_{8}$ & $\mathrm{~T}_{3}+$ Pseudomonas flurescens & 182.93 & 16.87 & 612.58 \\
\hline $\mathbf{T}_{9}$ & $\mathrm{~T}_{3}+$ Azotobacter chroococcum & 182.93 & 14.13 & 597.08 \\
\hline \multirow[t]{3}{*}{$\mathbf{T}_{10}$} & $\mathrm{~T}_{3}+$ Azospirillum lipoferum & 150.18 & 14.14 & 584.63 \\
\hline & S.E. \pm & 4.06 & 0.33 & 8.33 \\
\hline & C.D. at $5 \%$ & 10.05 & 1.19 & 23.73 \\
\hline
\end{tabular}


Table.3 Effect of co-inoculation of different bacterial cultures with Rhizobium phaseoli on DTPA extractable micronutrients in soil after harvest of black gram

\begin{tabular}{|c|c|c|c|c|c|}
\hline $\begin{array}{l}\text { Sr. } \\
\text { No. }\end{array}$ & Treatments & $\begin{array}{c}\text { DTPA Zn } \\
\left(\mathrm{mg} \mathrm{kg}^{-1}\right)\end{array}$ & $\begin{array}{c}\text { DTPA Fe } \\
\left(\mathrm{mg} \mathrm{kg}^{1}\right)\end{array}$ & $\begin{array}{c}\text { DTPA Cu } \\
\left(\mathrm{mg} \mathrm{kg}^{1}\right)\end{array}$ & $\begin{array}{c}\text { DTPA Mn } \\
\left(\mathrm{mg} \mathrm{kg}^{\mathbf{1}}\right)\end{array}$ \\
\hline $\mathbf{T}_{1}$ & Absolute control & 0.41 & 4.41 & 3.22 & 5.92 \\
\hline $\mathbf{T}_{2}$ & Only RDF & 0.43 & 4.55 & 3.39 & 6.32 \\
\hline $\mathbf{T}_{\mathbf{3}}$ & RDF + Rhizobium phaseoli & 0.46 & 4.73 & 3.43 & 6.48 \\
\hline $\mathbf{T}_{4}$ & $\mathrm{~T}_{3}+$ Bacillus megaterium & 0.58 & 5.03 & 3.99 & 6.94 \\
\hline $\mathbf{T}_{5}$ & $\mathrm{~T}_{3}+$ Bacillus subtilis & 0.54 & 4.82 & 3.70 & 6.31 \\
\hline $\mathbf{T}_{6}$ & $\mathrm{~T}_{3}+$ Bacillus polymyxa & 0.50 & 4.77 & 3.58 & 6.32 \\
\hline $\mathbf{T}_{7}$ & $\mathrm{~T}_{3}+$ Pseudomonas striata & 0.59 & 5.12 & 4.10 & 7.04 \\
\hline $\mathbf{T}_{8}$ & $\mathrm{~T}_{3}+$ Pseudomonas flurescens & 0.57 & 4.96 & 3.83 & 6.93 \\
\hline $\mathbf{T}_{9}$ & $\mathrm{~T}_{3}+$ Azotobacter chroococcum & 0.54 & 4.66 & 3.45 & 6.42 \\
\hline \multirow[t]{3}{*}{$\mathbf{T}_{10}$} & $\mathrm{~T}_{3}+$ Azospirillum lipoferum & 0.49 & 4.68 & 3.44 & 6.30 \\
\hline & S.E. \pm & 0.01 & 0.07 & 0.11 & 0.13 \\
\hline & C.D. at $5 \%$ & 0.04 & 0.21 & 0.31 & 0.39 \\
\hline
\end{tabular}

The treatment $\mathrm{T}_{7}\left(5.12 \mathrm{mg} \mathrm{ka}^{-1}\right)$ receiving coinoculation of Pseudomonas striata with Rhizobium phaseoli found significant over rest of treatments and found at par with treatment $\mathrm{T}_{8}\left(4.96 \mathrm{mg} \mathrm{kg}^{-1}\right.$ ) receiving co-inoculation of Pseudomonas flurescens with Rhizobium phaseoli and $\mathrm{T}_{4}\left(5.03 \mathrm{mg} \mathrm{kg}^{-1}\right)$ receiving coinoculation of Bacillus megaterium with Rhizobium phaseoli.

\section{DTPA extractable copper}

The maximum available $\mathrm{Cu}\left(4.10 \mathrm{mg} \mathrm{kg}^{-1}\right)$ was observed under treatment $\mathrm{T}_{7}(\mathrm{RDF}+$ Rhizobium phaseoli + Pseudomonas striata) which significantly differed from all other treatments. Treatments $\mathrm{T}_{4}\left(3.99 \mathrm{mg} \mathrm{kg}^{-1}\right)$ receiving co-inoculation of Bacillus megaterium with Rhizobium phaseoli and $\mathrm{T}_{8}$ (3.83 mg kg-1) receiving co-inoculation of Pseudomonas flurescens with Rhizobium phaseoli found at par with $\mathrm{T}_{7}$.

\section{DTPA extractable manganese}

Regarding to Mn the availability range varied from 5.92 to $7.04 \mathrm{mg} \mathrm{kg}^{-1}$ and treatment $\mathrm{T}_{7}$
(7.04 $\mathrm{mg} \mathrm{kg}^{-1}$ ) receiving co-inoculation of Pseudomonas striata with Rhizobium phaseoli found significant over rest of treatments and found at par with treatments $\mathrm{T}_{4}\left(6.94 \mathrm{mg} \mathrm{kg}^{-1}\right)$ having co-inoculation of Bacillus megaterium with Rhizobium phaseoli and $\mathrm{T}_{8}(6.93 \mathrm{mg}$ $\mathrm{kg}^{-1}$ ) having co-inoculation of Pseudomonas flurescens with Rhizobium phaseoli. The availability of micronutrient $(\mathrm{Zn}, \mathrm{Fe}, \mathrm{Cu}$ and $\mathrm{Mn}$ ) is might be due co-inoculation of bacterial cultures helps in mineralization which leads to organic forms into inorganic forms of nutrient hence its availability increases (Singh et al., 2016).

Our results are similar to the results reported by Kranthikumar et al., (2017b) that the available micronutrients in soil after harvest of soybean crop were influenced significantly with the inoculation of microbial cultures and recorded maximum in treatment receiving RDF + Rhizobium + Other microbial cultures. and it is due to production of growthpromoting substances and high colonization ability of rhizobacteria such as Pseudomonas because they enhance the nitrogen fixation when co-inoculated with Rhizobium. The $\mathrm{pH}$, 
EC and $\mathrm{CaCO}_{3}$ after harvest of black gram indicates non-significant results. But in case of soil organic carbon co-inoculation of Pseudomonas striata with Rhizobium phaseoli and RDF found superior over rest of the treatments. Significant increase in nutrient availability in soil after harvest of black gram crop was also recorded with co-inoculation of bio-inoculants. Significantly highest value of available $\mathrm{P}_{2} \mathrm{O}_{5}$ were noted in treatment receiving Pseudomonas fluorescens along with Rhizobium phaseoli and RDF and availability of $\mathrm{N}, \mathrm{P}_{2} \mathrm{O}_{5}$ and $\mathrm{K}_{2} \mathrm{O}$ enhanced due to application of Pseudomonas striata along with Rhizobium phaseoli. The DTPA extractable micronutrients $(\mathrm{Fe}, \mathrm{Mn}$ and $\mathrm{Cu}$ ) found significantly increased by coinoculation Pseudomonas striata with Rhizobium phaseoli. In case of soil DTPA Zn treatment having co-inoculation of Pseudomonas flurescens with Rhizobium phaseoli shows significant result over others and found at par with treatment having coinoculation of Pseudomonas striata with Rhizobium phaseoli.

\section{References}

Amule, F.C., Rawat, A.K. and Rao D.L.N. (2017) Co-inoculation response of Rhizobium and PGPR on soybean and chickpea. International Journal of Chemical Studies 5(6), 2094-2102.

Anonymous (2018) Pulses Revolution From Food to Nutritional Security, Crops Division, Government of India, Ministry of Agriculture \& Farmers Welfare, (Department of Agriculture), Cooperation \& Farmers Welfare Krishi Bhavan, pp.20, New Delhi - 110001

Dashadi, M., Khosravi, H., Moezzi, A., Nadian, H., Heidari, M. and Radjabi, R. (2011) Co-inoculation of Rhizobium and Azotobacter on growth indices of faba bean under water stress in the greenhouse condition. Advanced
Studies in Biology 3(8), 373-385.

Dhage, S.J. and Kacchave, K.G. (2008) Effect of dual inoculation of Rhizobium and PSB on yield contributing characters and seed yield of soybean. Journal of Maharashtra Agricultural University 33(2), 209-211.

Elangaimannan, R., Anbuselvam, Y. and Karthikeyan, P. (2008) Genetic diversity in black gram [Vigna mungo (L.) Hepper]. Legume Research 31(1), 57-59.

Goutami, N., Rani, P.P., Pathy, R.L. and Babu, P.R. (2015) Soil properties and biological activity as influenced by nutrient management in rice- fallow sorghum. International Journal Agricultural Research, Innovation and Technology 5(1), 10-14.

Kranthikumar, B., Ismail Syed and Patil V.D. (2017a) Role of microbial solubilisers on major nutrient uptake- A review. Journal of Pharmacognosy and Phytochemistry 6(5), 641-644.

Kranthikumar, B., Ismail Syed, Manasa K. and Pawar A. (2017b) Enhancement of nutrient availability in soil using microbial cultures in soybean grown on Vertisol. International Journal of Current Microbiology and Applied Sciences 6(5), 2802-2807.

Kumar, P.S., Aruna Geetha, S., Savithri, P., Jagadeeswaran, R. and Ragunath, $\mathrm{K}$. (2004) Effect of $\mathrm{Zn}$ enriched organic manures and zinc solubilizer application on the yield, curcumin content and nutrient status of soil under turmeric cultivation. Journal of Applied Horticulture 6(2), 82-86.

Mishra, P.K., Bisht, S.C., Ruwari, P., Joshi, G.K., Singh, G. Bisht, J.K. and Bhatt, J.C. (2011) Bioassociative effect of cold tolerant Pseudomonas spp. and Rhizobium leguminosarum-PR1 on iron acquisition, nutrient uptake and growth of lentil (Lens culinaris). 
European Journal of Soil Biology 47, 35-43.

Nirmal De, Singh, R.K., Kumar, A. and Singh, J. (2006) Effect of organic inputs and biofertilizers on biomass, quality and yield parameters of vegetables pea (Pisum sativum L.). International Journal of Agricultural Science 2(2), 618-620.

Panse, V. G. and Sukhatme, P. V., (1967) Statistical Methods for Agricultural Workers, Indian Council of Agricultural Research, New Delhi.

Qureshi, M.A., Shakir, M.A., Iqbal, A., Akhtar, N. and Khan, A. (2011) Coinoculation of phosphate solubilizing bacteria and rhizobia for improving growth and yield of mungbean (vigna radiata L.) The Journal of Animal \& Plant Sciences 21(3), 491-497.

Shashidhar, K.R., Narayanaswamy, T.K., Bhaskar, R.N., Jagadish, B.R. (2009) Influence of organic based nutrients on soil health and mulberry (Morus Indica L.) production. E-Journal Biological
Sciences 1(1), 94-100.

Singh, G., Choudhary, P., Meena, B.L., Rawat R.V. and Jat B.L. (2016) Integrated nutrient management in black gram under rainfed condition. International Journal of Recent Scientific Research 7(10), 13875-13894.

Verma, J.P., Yadav, J. and Tiwari K.N. (2010) Application of Rhizobium $s p$. BHURC01 and plant growth promoting rhizobacteria on nodulation, plant biomass and yields of chickpea (Cicer arietinum L.). International Journal of Agricultural Research 5(3), 148-156.

Vidhyashree, C.V., Naga, S.R., Yadav, B.L., Shivran, A.C. and Singh, S.P. (2017) Influence of phosphorus and biofertilizers on soil fertility and enzyme activity of soils grown under mungbean (Vigna radiata L. Wilczek). International Journal of Current Microbiology and Applied Science 6(12), 737-741.

\section{How to cite this article:}

Nelwade, K. M., Syed Ismail and Jadhav, R. A. 2019. Nutrient Dynamics in Blackgram (Vigna mungo) Grown Vertisols as Influenced by Co-inoculation of Different Bacterial Cultures with Rhizobium phaseoli. Int.J.Curr.Microbiol.App.Sci. 8(10): 554-561.

doi: https://doi.org/10.20546/ijcmas.2019.810.060 